\title{
Janīna Danusēviča
}

(1928-2016)

Krājuma "Acta medico-historica Rigensia" veidošanas komanda ar skumjām paziņo, ka 2016. gada 9. augustā mirusi Paula Stradiña Medicīnas vēstures muzeja ilggadēja darbiniece, visu krājuma iepriekšējo deviņu sējumu redaktore Janīna Danusēviča.

Anatome, medicīnas tekstu redaktore Janīna Danusēviča dzimusi 1928. gada 7. jūlijā Rīgā. 1955. gadā viña absolvēja Rīgas Medicīnas institūtu, saņemot ārsta diplomu, un uzreiz tika pieņemta darbā institūta Normālās anatomijas katedrā, kur docēja 1955.-1958. gadā un 1962.-1967. gadā. No 1958. līdz 1962. gadam J. Danusēviča mācīja anatomiju arī Latvijas Fiziskās kultūras institūta studentiem. No 1967. līdz 1972. gadam viņa bija praktizējoša ārste Saldū.

Taču savu dzīves piepildījumu Janīna Danusēviča atrada medicīnas literatūras zinātniskās redaktores darbā. Gandrīz 15 gadus, no 1973. līdz 1987. gadam, viņa strādāja par zinātnisko redaktori Galvenajā enciklopēdiju redakcijā bioloǵisko zinātņu, ķīmijas un medicīnas nodal̦ā. Šajā laikā viņas profesionālo redzesloku papildināja vispārējās biologijjas un medicīnas vēstures jautājumi. Jan̄̄na Danusēviča rediǵeja medicīniskās tematikas rakstus gan Latvijas Padomju enciklopēdijas 10 sējumiem, gan Populārajai medicīnas enciklopēdijai, kas sniedza primāro informāciju par medicīnu tā laika Latvijas iedzīvotājiem. Viña ir arī daudzu enciklopēdijas zinātnisko rakstu autore. Galvenajā enciklopēdiju redakcijā iegūtās redigèešanas zināšanas līdz ar izcilo medicīnas pārzināšanu Janīna Danusēviča izmantoja nākamo trīsdesmit gadu laikā, rediǵējot ḷoti daudzas medicīniska satura grāmatas.

Viṇai bija ne tikai teicama valodas izjūta, bet arī medicīniskās un kultūras zināšanas. Caur viņas rokām daudzu gadu garumā dienas gaismu ieraudzīja neskaitāmas zinātniskas publikācijas, disertācijas un monogrāfijas. 
Paralēli pamatdarbam viņa turpināja arī pedagoǵisko praksi kā privātskolotāja, palīdzot studentiem apgūt anatomiskās zināšanas.

No 1992. gada Janīna Danusēviča bija Paula Stradiņa Medicīnas vēstures muzeja rakstu krājuma "Acta medico-historica Rigensia" zinātniskā redaktore. 1994. gadā viņa sāka strādāt par eksponātu glabātāju Jēkaba Prīmaņa Anatomijas muzejā, vēlāk - par muzeja galveno speciālisti. Muzejā viņa nostrādāja līdz 2015. gadam.

Janīnas labās un atsaucīgās sirds mīlestība bija mūzika. Viņas bērnībā iegūtā muzikālā izglītība tika pilnveidota konservatorijā. Viṇa bija izcila klasiskās mūzikas pazinēja, apmeklēja visus ievērojamākos muzikālos notikumus Latvijā, un katrā Latvijas Nacionālās operas pirmizrādē viņa bija redzama savā iemīlotajā vietā partera kreisās puses desmitajā rindā. Pēdējos gados šĩ saskarsme ar skaisto notika ar Latvijas Radio programmas "Klasika" tiešraidēm un gadu desmitiem vākto nošu un klasiskās mūzikas personīgo fonotēku.

Visas dz̄ives garumā Janīnai Danusēvičai būtiska bija viņas poḷu izcelsme. Viņa ļoti labi zināja poļu, vācu, arī krievu valodu. Atmodas gados Janīna Danusēviča bija viena no Latvijas Poḷu biedrības atjaunotājām, aktīvi līdzdarbojoties poḷu kultūras dzīvē. Janīnai visā pasaulē bija ļoti daudz draugu, ar kuriem viņu saistīja ilggadēja sarakste. Daudzas šīs draudzības bija sākušās jau jaunībā un ar sarakstes palīdzību turpinājās visu mūžu.

Par savu darbu, nesavtīgo dāsnumu Janīna Danusēviča saņēma pagodinājumus un atzinības, bet īpaši viņa priecājās, kad 2009. gadā tika ievēlēta par Latvijas Ārstu biedrības goda biedri.

Katrā cilvēkā, ko Janīna Danusēviča reiz satikusi, ir palikusi kaut neliela viņas dzirksts. Bet viṇas pašas, sirsnīgas kolēges un brīnišşı̄ga cilvēka sirds nu ir apklususi.

Sit tibi terra levis!

Rita Grāvere, Dr. hist.

Paula Stradiña Medicīnas vēstures muzejs rita_gravere@inbox.lv 